\title{
Rumen-protected B vitamin complex supplementation during the transition period and early lactation alters endometrium mRNA expression on day 14 of gestation in lactating dairy cows
}

\author{
Manveen Kaur, ${ }^{1}$ Ivan Hartling, ${ }^{1}$ Tracy A. Burnett, ${ }^{1}$ Liam B. Polsky, ${ }^{1}$ Charlotte R. Donnan, ${ }^{1}$ Hélène Leclerc, ${ }^{2}$ \\ Douglas Veira, ${ }^{1}$ and Ronaldo L. A. Cerri ${ }^{1 *}$ \\ ${ }_{1}^{1}$ Applied Animal Biology, Faculty of Land and Food Systems, University of British Columbia, Vancouver V6T 1Z4, BC, Canada \\ ${ }^{2}$ Jefo, Saint-Hyacinthe J2S 7B6, QC, Canada
}

\section{ABSTRACT}

Greater metabolic demands in high-producing dairy cows are believed to be a cause of sub-fertility in these animals. Previously, supplementation with vitamin B complex molecules has shown benefits in improving milk production, health, and reproductive efficiency of dairy cows. The primary aim of this project was to determine the effects of rumen-protected vitamin B complex supplementation of $100 \mathrm{~g}$ of Transition VB (Jefo, St. Hyacinthe, QC, Canada) and $4 \mathrm{~g}$ of Lactation VB (VB; Jefo), during the transition and early lactation periods, respectively, compared with a control diet containing no supplementation on d 14 endometrial outcomes of pregnancy. In the vitamin B supplemented cows, we expect to see a change in the mark-up of endometrial genes important for embryo survival before implantation. Multiparous Holstein cows were enrolled into the study 3 wk before parturition and were randomly assigned to either the VB or control treatment. Twice-a-week blood samples, weekly milk samples, and daily feed intake were collected. Cows were enrolled onto a double-ovsynch protocol at $33 \pm 3 \mathrm{~d}$ postpartum and inseminated by timed artificial insemination. Milk production and components, concentrations of BHB, haptoglobin, and progesterone in serum, and ovarian dynamics were also measured, but no treatment effect was observed. The uterus was flushed on d 14 after artificial insemination (around 72 DIM) for conceptus collection, and endometrial samples were collected at the same time. Overall, 42 cows were flushed and 13 embryos were collected. Analysis of mRNA expression of genes related to embryo development, immune system, adhesion, and regulation of vitamin B molecules

Received February 22, 2018.

Accepted August 23, 2018.

*Corresponding author: ronaldo.cerri@ubc.ca showed that $O X T R, M U C 5 B, M U C 1, I L 1 B, S P P, T R D$, $F Z D 8$, and FOLR1 genes were significantly upregulated in the VB group. Vitamin B supplementation had no effect on the size of the embryo and ovulatory follicle or corpus luteum diameter at embryo collection. In conclusion, the benefits of strategic dietary VB supplementation during the transition and early lactation might be directly linked to endometrial functions required for embryo survival during the peri-implantation period. Key words: dairy cow, endometrium, mRNA expression, rumen-protected B vitamins

\section{INTRODUCTION}

Vitamin B complex molecules are vital as cofactors to several metabolic processes, including fatty acid transport and milk protein synthesis (Table 1). Vitamin B molecules are synthesized by ruminal bacteria and it was believed that the ruminal synthesis meets the requirements to prevent deficiency symptoms in ruminants, a postulation supported by NRC (2001). The NRC (2001) calculated an estimate and reported only folic acid and pantothenic acid to be the limiting B vitamins. However, in the recent past, numerous studies have shown an increase in milk production or component yield (or both) when cows are supplemented with vitamin B compounds (Sacadura et al., 2008; Chen et al., 2011; Evans and Mair, 2013). Similarly, a positive effect of supplementation on health has also been reported, especially in early lactation dairy cows (Graulet et al., 2007; Duplessis et al., 2014; Li et al., 2016), which is achieved via improvement in metabolic efficacy. Based on results reported by Santschi et al. (2005), Schwab et al. (2006), and Sacadura et al. (2008), a deficit for folic acid, pantothenic acid, and pyridoxine was estimated in cows, which indicates that the requirements for B vitamins could have changed in modern dairy cows.

Evidence of improvement in pregnancy per AI in the first postpartum AI in cows supplemented with a combination of rumen-protected B vitamins has been 
Table 1. Functions of supplemented vitamins included in the rumen-protected B vitamin treatment

\begin{tabular}{lll}
\hline Vitamin & Phase & Function \\
\hline Riboflavin & Transition & Coenzyme in energy, carbohydrate, lipid, and AA metabolism \\
Choline & Transition & Lipid metabolism, one-carbon metabolism, and cellular signaling \\
Folic acid & Transition + lactation & One-carbon metabolism and DNA synthesis (purine production) \\
$\mathrm{B}_{12}$ & Transition + lactation & One-carbon metabolism, methionine synthesis, and DNA synthesis \\
Pyridoxine & Lactation & Co-factor in protein, lipid, and carbohydrate metabolism \\
Pantothenic acid & Lactation & Co-factor as CoA in pathways involving oxidative respiration, lipid metabolism, and steroid \\
& Lactation & and prostaglandin synthesis \\
Biotin & Keratin synthesis and as co-factor for carboxylase enzymes involved in fatty acid synthesis, \\
& AA catabolism, and gluconeogenesis \\
\hline
\end{tabular}

demonstrated by Juchem et al. (2012). It is unclear, however, the cellular or molecular mechanism by which this reproductive improvement was achieved. Intramuscular injections of folic acid and vitamin $\mathrm{B}_{12}$ from 3 wk prepartum to 8 wk postpartum resulted in higher expression of genes associated with granulosa cell differentiation before ovulation, which was suggested to be an effect of increased LH secretion in animals receiving supplemental injections (Gagnon et al., 2015). Recently, Richard et al. (2016) reported that the dietary supplementation of rumen-protected B vitamins affected the differentiation of granulosa cells of dominant follicles toward an earlier LH response associated with genes expressed in conditions where oocyte developmental competence is improved. Considering that, the vitamin B complex could also potentially affect many genes or functional groups of interest in the endometrium. During the pre-attachment phase, the IFN- $\tau$ produced by the conceptus induces an array of changes in the uterus by promoting the expression of IFN-stimulated genes, genes related to cell remodeling, adhesion and invasion, cell orientation and polarization, angiogenesis, and transporters of glucose and lipids (Bauersachs et al., 2006; Spencer et al., 2008; Forde et al., 2010). The goals of the project were to determine the effect of rumen-protected B vitamin supplementation, which delivers the supplement postruminally, compared with a control diet containing no supplement on (1) endometrial mRNA expression of target transcripts related to embryo development, immune function, and cellular adhesion on d 14 of pregnancy, (2) milk production and plasma BHB and haptoglobin concentrations early postpartum, and (3) ovarian follicle growth and plasma levels of progesterone during the key points of reproductive cycle in the experiment.

We hypothesize that supplementing rumen-protected B vitamins will improve follicle growth and ovarian steroid synthesis. Milk production is expected to increase, but with no deleterious effect on the metabolic profile early postpartum. Furthermore, we expect that the vitamin B supplementation will improve the make-up of expression of key transcripts pivotal to pre-attachment embryonic development.

\section{MATERIALS AND METHODS}

This study was conducted at the University of British Columbia Dairy Education and Research Centre, Agassiz, from March to December 2015. The practices recommended by the Canadian Council on Animal Care (CCAC, 2009) were followed, and the local Institutional Animal Care Committee approved the study.

\section{Animals and Experimental Design}

Forty-two multiparous Holstein cows were enrolled 3 wk before expected calving date and assigned randomly to either rumen-protected B vitamins (VB) or control (Con) groups. The 2 treatment groups were balanced for previous lactation milk production. The VB group was supplemented with $100 \mathrm{~g} /$ cow per day of rumen-protected B vitamins and choline for transition cows (Transition VB, Jefo, St. Hyacinthe, QC, Canada), containing choline, riboflavin, folic acid, and vitamin $\mathrm{B}_{12}$ ) from 3 wk prepartum to 14 DIM and with $4 \mathrm{~g}$ of rumen-protected $\mathrm{B}$ vitamins for lactating cows (Lactation VB, Jefo), containing folic acid, vitamin $\mathrm{B}_{12}$, biotin, pyridoxine, and pantothenic acid, diluted with $36 \mathrm{~g}$ of a palmitic fat source, from 15 DIM until endometrial biopsy (around 72 DIM). The transition rumen-protected B vitamins blend contained $50 \mathrm{~g}$ of a palmitic fat source and the lactation rumen-protected $\mathrm{B}$ vitamins was diluted with $36 \mathrm{~g}$ of a similar palmitic fat source; therefore, the Con treatment during the entire experimental period was also offered the same amount of supplemental fat as the VB treatment.

Cows were housed in freestall barns and fed a TMR to meet or exceed the requirements of a $750-\mathrm{kg}$ pregnant Holstein cow around $270 \mathrm{~d}$ of pregnancy, during the close-up period before calving and for a $620-\mathrm{kg}$ Holstein cow producing $40 \mathrm{~kg} / \mathrm{d}$ of $3.5 \%$ FCM during the postcalving period (NRC, 2001). The pens were 
equipped with an automated electronic feed and water intake system (Insentec, Marknesse, the Netherlands). The cows were fed twice a day and all cows were given ad libitum access to feed and water. To be identified by the electronic system, each cow was tagged with their own passive transponder to their ear tag. A panel fitted above each bin read a cow's transponder and thereby allowed her to reach feed if she was assigned to access a particular bin. The system captured feed intake of individual cows.

\section{Milk Sample Collection and Analysis}

The cows were milked twice a day, milk production of experimental cows was recorded daily, and information was collected from Dairy Comp 305 (Valley Ag Software, Tulare, CA). Milk samples were collected weekly starting from the first week postpartum until the end of the study. The evening (pm) and morning (am) milk samples were collected into a plastic container containing a dissolvable milk fat preservative (BroTab10, Systems Plus, Baden, ON, Canada) during the normal milking time. The weekly milk samples were analyzed for milk fat \%, protein \%, and SCC at a commercial milk testing laboratory (Canwest DHI, Chilliwack, BC, Canada).

\section{Ultrasonography}

Real-time per rectum ultrasonography, using a portable ultrasound scanner with $7.5-\mathrm{MHz}$ linear-array transducer (Ibex Pro, E.I. Medical Imaging, Loveland, $\mathrm{CO}$ ), was used to monitor ovarian and uterine structures. With the onset of Ovsynch treatment, ultrasonography was carried out on the days of GnRH and $\mathrm{PGF}_{2 \alpha}$ injections to determine the ovulation response, follicle number and diameter, and corpus luteum (CL) diameter on both ovaries. During the study, the uterus was assessed for state of involution and any other abnormalities and the ovaries for follicles and CL.

\section{Synchronization of Ovulation Protocol and Al}

All cows were placed on a presynchronization-synchronization reproductive management protocol and assigned to be bred by timed AI. Presynch was initiated with an i.m. injection of GnRH (100 $\mu \mathrm{g}$; Cystorelin, Merial, Duluth, GA) at $33 \pm 3$ d after parturition, followed $7 \mathrm{~d}$ later by an injection of $\mathrm{PGF}_{2 \alpha}$ (25 mg; Lutalyse, Pfizer Animal Health, New York, NY) and another GnRH injection $2 \mathrm{~d}$ after the $\mathrm{PGF}_{2 \alpha}$ injection. At 7 $\mathrm{d}$ after $\mathrm{PGF}_{2 \alpha}$, the ovulation synchronization protocol was initiated by administering $100 \mu \mathrm{g}$ of $\mathrm{GnRH}$ and inserting an intravaginal progesterone insert (CIDR; Easi-Breed, Pfizer Animal Health) for 7 d. Cows received an injection of $\mathrm{PGF}_{2 \alpha}$ at the time of CIDR removal and another one $12 \mathrm{~h}$ later. A final GnRH $(100 \mu \mathrm{g})$ was given $56 \mathrm{~h}$ after the first $\mathrm{PGF}_{2 \alpha}$ injection and timed $\mathrm{AI}$ was at the time of the last GnRH injection and $12 \mathrm{~h}$ later. Artificial insemination followed the University of British Columbia farm guidelines.

\section{Blood Samples for Haptoglobin, BHB, and Progesterone Analysis}

Blood samples from the median coccygeal vein or artery were collected in two $10-\mathrm{mL}$ tubes containing EDTA and clot activator, respectively. The blood samples were collected biweekly during the transition period, before administering the ovsynch injections and at $\mathrm{d} 2,5,7,12$, and 14 post-AI. The samples were centrifuged at $2,000 \times g$ for $15 \mathrm{~min}$ at $5^{\circ} \mathrm{C}$ to obtain plasma and serum and were stored at $-80^{\circ} \mathrm{C}$.

The plasmatic haptoglobin quantification was performed by ELISA, based on formation of hemoglobinhaptoglobin complexion, estimating the difference of activity of peroxidase in the plasma (Makimura and Suzuki, 1982). An ELISA reader (Gemini EM, Molecular Devices, Sunnyvale, CA) was configured for $450 \mathrm{~nm}$ of wavelength to evaluate the colorimetric reaction. The intra- and interassay coefficients of variation were 4.8 and $7.6 \%$, with 0.95 optical density as the minimum detectable value. Serum progesterone concentrations were determined using a commercial ELISA kit (Ovucheck Plasma, Biovet, St. Hyacinthe, QC, Canada) according to the manufacturer's instructions. The intra- and interassay coefficients of variation were 8.3 and $15.7 \%$, with $0.5 \mathrm{ng} / \mathrm{mL}$ as the minimum detectable concentration. Whole-blood BHB levels were measured using a handheld meter (Precision Xtra BHB test, Abbott Laboratories, Chicago, IL), validated for cow-side use (Iwersen et al., 2009).

\section{Feed Sampling and Analysis}

Feed and supplement samples were collected once a week for the duration of the study and pooled together into monthly samples. Then samples were dried at $55^{\circ} \mathrm{C}$ for $48 \mathrm{~h}$ to determine the DM content and ground thoroughly. Pooled monthly samples were sent to a commercial laboratory (Cumberland Valley Analytical Services, Waynesboro, PA) for nutrient composition analysis (Table 2).

\section{Conceptus Collection and Endometrial Biopsy}

Forty-two cows had their uteri flushed on d 14 after AI for conceptus collection followed by endometrial biopsy. A total of 7 and 6 conceptuses $(n=13)$ were re- 
covered from the Con and VB group, respectively. The day before biopsy, animals were scanned to confirm the presence of CL and its side. On the day of flushing, the cows were administered epidural anesthesia, using $2 \mathrm{~mL}$ of $2 \%$ lidocaine (Bimeda MTC Animal Health, Cambridge, ON, Canada), followed by external genitalia cleaning.

For uterine flushing and embryo collection, the cervix was transpassed by a Foley catheter (20 French), and commercial flushing solution (Bioniche Animal Health Canada, Belleville, ON, Canada) was used. The embryos were then recovered and measured. Uterine biopsy was performed immediately after uterine flushing, through an endometrial biopsy forceps (Kevorkian-Younge, Fine Surgicals, and $3.5 \times 8.0 \mathrm{~mm}$ bite and $50.8 \mathrm{~cm}$ shaft), driving it to the ipsilateral uterine horn. Around 100 to $200 \mathrm{mg}$ of endometrial tissue was collected from each cow. The samples were immediately after transferred to a 2-mL DNAase and RNAase freetube, filled by RNAlater (Qiagen, Ambion, TX), and stored at $-80^{\circ} \mathrm{C}$.

\section{RNA Extraction}

The RNA extraction of frozen endometrial and conceptus tissues was performed using total RNA isolation solution, Tri Reagent (Invitrogen, Carlsbad, CA) and a commercial kit (PureLink, Invitrogen), following the manufacturer's instructions. The quantitative RNA measurement was performed by spectrophotometry (Nano Drop 2000, Thermo Scientific, Wilmington, DE).

Table 2. Ingredient and nutrient composition of feed during close up and lactation phases

\begin{tabular}{lcc}
\hline Item & Close up & Lactation \\
\hline Ingredient component (\% of DM) & & \\
Corn silage & 22.6 & 32.6 \\
Grass silage & - & 14.2 \\
Alfalfa hay & 38.1 & 5.3 \\
Rye grass seed straw & 25.3 & - \\
Dry cow mix & 14.1 & - \\
Regular complete mash & - & 47.9 \\
Nutrient (\% of DM) & 14.5 & \\
CP & 5.9 & 16.8 \\
Soluble protein & 33.3 & 18.4 \\
ADF & 43.6 & 30.6 \\
NDF & 6.1 & 1.7 \\
Lignin & 8.7 & 23.6 \\
Starch & 2.3 & 4.1 \\
Ether extract & 8.8 & 8.9 \\
Ash & 0.98 & 0.84 \\
Ca & 0.31 & 0.45 \\
P & 0.28 & 0.33 \\
Mg & 1.99 & 1.83 \\
K & 0.27 & 0.28 \\
S & 0.87 & 0.37 \\
Supplemented Met (g/kg of DM) & 0.52 & 0.27 \\
Se (mg/kg) &
\end{tabular}

\section{Analysis of mRNA Expression}

Expression levels of 96 target genes (Table 3) in endometrial biopsy samples were measured on the NanoString nCounter Analysis System (NanoString Technologies, Seattle, WA). The nCounter assay is based on direct imaging of mRNA molecules of interest that are detected using target-specific, color-coded probe pairs, called the reporter and capture probes, which were custom designed for 96 target and 4 reference genes (Appendix Table A1). Approximately 150 ng of the target mRNA was mixed in solution with a large excess of the reporter and capture probe pairs, so that each targeted transcript found its corresponding probe pair. The hybridization reaction was carried out for $22 \pm 0.5 \mathrm{~h}$ in a standard thermocycler at $65^{\circ} \mathrm{C}$, with $\geq 70^{\circ} \mathrm{C}$ lid temperature to avoid condensation. After hybridization, the sample and probe solutions, along with the reagents and consumables were loaded in the NanoString Prep station, which is a multi-channel pipetting robot that processes samples to prepare them for data collection on the Digital Analyzer. In the preparatory station, excess unbound probes were washed away and the tripartite complexes, comprising target mRNA bound to specific reporter-capture probe pairs, were isolated. The biotin label at the $3^{\prime}$ end of the capture probes was used to attach the complexes to streptavidin-coated slides. An electric field was applied to orient and extend the tripartite complexes on the surface of the slide to facilitate imaging and detection of the color-coded molecules. A microscope objective and a charge-coupled device camera in the Digital Analyzer were then used to image the immobilized complexes using 4 different excitation wavelengths (480, 545, 580, and $622 \mathrm{~nm}$ ) corresponding to the 4 fluorescent dyes. The different combinations of the 4 distinct colors allows for a large diversity of color-based barcodes, each designating a different gene transcript. The expression level of a gene is measured by counting the number of times the specific barcode is detected, and the barcode counts are tabulated in a comma-separated value (CSV) format. The protocol was performed from start to finish, including hybridization, posthybridization processing, and digital data acquisition, on the nCounter System. Processing of raw data as well as quality control and data normalization was performed in the nSolver analysis software by Nanostring. The system used 4 reference genes with different expression levels for optimal normalization.

\section{Statistical Analysis}

Uterine mRNA expression data were analyzed on 13 cows from which an embryo was recovered during flush- 
Table 3. List of genes analyzed, grouped according to their role in the tissues

\begin{tabular}{|c|c|}
\hline Function & Genes \\
\hline Immune system & $\begin{array}{l}\text { IGLL1, SELL, CXCL10, PTX3, TRD, MX2, IL10, IDO, LIFR, IGHG1, SLPI, LYZ2, UHRF1, CXCL8, IL1B, } \\
\text { TNFA, NFKB1, MUC1, B-Defensin, B3GAT1, NR1I2 }\end{array}$ \\
\hline Growth and development & $\begin{array}{l}\text { CTNNB1, WNT2, DKK1, AXIN1, AXIN2, APC,FZD7,GSK3ß, MSX1, RELN, FZD8, WNT3, FZD4, AGPAT, } \\
\text { IGF1, IGF2, IGF1R, IGFBP1, IGFBP2, IGFBP3, VEGFA, WNT3A, CXXC4, CAPN6, PFKFB2, MOGAT1, } \\
\text { DGKA, CALB2 }\end{array}$ \\
\hline Nutrient metabolism & NNMT \\
\hline Morphogenesis & PLAU, HOXB7, BMP15, GPX4, EEF1A1, IL6, FTH1 \\
\hline $\begin{array}{l}\text { Maternal recognition of } \\
\text { pregnancy }\end{array}$ & $I F N T, I S G 15$ \\
\hline Housekeeping & $A C T B, G A P D H, P G K 1, R P L 19$ \\
\hline
\end{tabular}

ing. A power analysis test was done to determine the minimum number of experimental units. The variable in question was fold-change mRNA expression and the genes evaluated were previously researched in 2 studies (Cerri et al., 2012; Davoodi et al., 2016). Five genes with different baseline levels and proposed differences with a possible biological effect (at least a 1.25-foldchange difference) were evaluated, and the one (TRD) that yielded the largest sample size was then used to determine the final number of pregnant animals required for analysis of endometrial mRNA expression differences.

The data were analyzed for normality using the PROC UNIVARIATE from SAS (version 9.4, SAS Institute Inc., Cary, NC) and tested for homogeneity of variance by the Kolmogorov-Smirnov procedure. Six transcripts had their mRNA expression data log-transformed. An ANOVA for repeated measures using PROC MIXED of SAS was used for treatment differences when analyzing for milk production and components and plasma concentrations of BHB, haptoglobin, and progesterone. PROC MIXED was also used to analyze the mRNA expression data in the uterus and Tukey's test was used for post hoc analysis to correct for family-wise error rate. Dichotomous outcomes (pregnancy outcome and disease incidence) were evaluated by logistic regression using the LOGISTIC procedure of SAS software (SAS Institute Inc.).

\section{RESULTS}

Results from the endometrial mRNA expression analysis from 13 pregnant cows $(\mathrm{Con}=7 ; \mathrm{VB}=6$ ) showed that 11 genes that play a role in immune system, adhesion, steroid hormone regulation, and nutrient transportation were different between cows that became pregnant in the VB and Con group (Table 4;
Figure 1). MUC5B and SPP1 were upregulated significantly in VB group with a $3.32(P=0.05)$ and 2.02 $(P=0.03)$ fold increase, respectively, whereas $M Y H 9$ showed a tendency to be upregulated in the VB animals with a fold increase of $1.09(P=0.10)$. These genes are involved in the regulation of adhesion proteins in the endometrium. Endometrial immune system regulators TRD, IL1 $\beta$, and $M U C 1$ were significantly upregulated, whereas SELL showed a tendency for increased expression in VB animals. The fold change differences observed in this group were $1.84(P=0.03), 2.01(P$ $=0.05), 2.46(P=0.02)$, and $1.52(P=0.10)$, respectively. Other genes upregulated significantly in the VB group were FOLR1 (fold change $=1.54 ; P=0.05$ ), $O X T R$ (fold change $=2.02 ; P=0.04$ ), and FZD8 (fold change $=1.18 ; P=0.05)$, which are involved in folate transportation, oxytocin action regulation, and Wnt signaling. PLAU, which plays a role in embryo morphogenesis, also showed a tendency to be upregulated in VB animals with a fold difference of $1.49(P=0.1)$.

Supplementation with rumen-protected B vitamins did not affect concentrations of BHB (Figure 2a) or haptoglobin (Figure 2b) in plasma during the transition period $(P=0.84, P=0.92)$. Milk production $(P$ $=0.90$, Figure 3a), milk fat $(P=0.86$, Figure $3 \mathrm{~b})$, and milk protein $(P=0.37$. Figure $3 \mathrm{~b})$ contents were also similar between the VB and Con groups. Feed intake was also similar between the 2 groups $(P=0.94$, Figure 3c). However, pregnant animals had a significantly higher feed intake compared with nonpregnant cows, irrespective of the treatments $(20.19 \pm 0.31$ vs. $19.33 \pm$ $0.21 \mathrm{~kg} / \mathrm{d} ; P=0.02)$.

Vitamin B supplementation had no effect on the length of the embryo (Figure 4), ovulatory follicle (18.4 \pm 0.7 vs $19.1 \pm 0.7 \mathrm{~mm} P=0.51)$, or CL diameter at embryo collection $(29.3 \pm 1.2$ vs $30.5 \pm 1.3 ; P=$ 0.51 for Con vs. VB, respectively). Concentration of 
Table 4. Absolute mRNA expression in the endometrium from control $(\mathrm{Con} ; \mathrm{n}=7)$ and rumen-protected $\mathrm{B}$ vitamins $(\mathrm{VB} ; \mathrm{n}=6)$ treatment cows on $\mathrm{d} 14$ of pregnancy

\begin{tabular}{|c|c|c|c|c|}
\hline Functional group & Gene & $\mathrm{VB}$ & Con & $P$-value \\
\hline Steroid biosynthesis and regulation & $O X T R$ & $498.5 \pm 105.6$ & $246.3 \pm 97.7$ & 0.04 \\
\hline Immune system & $S E L L$ & $179.9 \pm 29.5$ & $118 \pm 27.3$ & 0.10 \\
\hline Immune system & $M U C 1$ & $1,808.1 \pm 1.1$ & $735.1 \pm 1.1$ & 0.02 \\
\hline Immune system & $I L 1 B$ & $109.9 \pm 1.2$ & $54.6 \pm 1.2$ & 0.05 \\
\hline Immune system & $T R D$ & $1,324 \pm 247$ & $720 \pm 223$ & 0.03 \\
\hline Adhesion molecules & $S P P 1$ & $447.6 \pm 1.2$ & $222.1 \pm 1.2$ & 0.03 \\
\hline Adhesion molecules & $M U C 5 B$ & $812.4 \pm 1.5$ & $244.7 \pm 1.5$ & 0.05 \\
\hline Adhesion molecules & МYH9 & $5,962.7 \pm 219.9$ & $5,461.7 \pm 203.7$ & 0.10 \\
\hline Morphogenesis & $P L A U$ & $366.4 \pm 1.1$ & $245.5 \pm 1.1$ & 0.1 \\
\hline Growth and development & $F Z D 8$ & $211.2 \pm 12.1$ & $179.5 \pm 11.2$ & 0.05 \\
\hline Nutrient transporters & FOLR1 & $1,570.2 \pm 102.7$ & $1,022 \pm 95.0$ & 0.05 \\
\hline
\end{tabular}

progesterone in plasma measured during key points of the ovsynch protocol and on $\mathrm{d} 2,5,7,12$, and 14 were also similar between the 2 groups $(P=0.80$, Figure 5$)$.

\section{DISCUSSION}

From fertilization to term, several molecules and systems work in synchrony to receive and maintain the conceptus. It is reasonable to hypothesize that the potential benefits from vitamin B complex strategic supplementation during the transition and peak lactation periods could come from direct influence of these molecules in the reproductive tract as well as indirect effects from better metabolic status and health. In this study, we observed 8 genes that were upregulated and were grouped according to their functionality (Table 4 ), which could cause changes in molecular mechanisms in the uterus able to promote a favorable uterine environment for the establishment of the pre-implanted embryo. The importance of regulation of these functional transcripts still needs further investigation, but it is indicative that dietary supplementation of rumenprotected B vitamins, as offered in the current study, can potentially improve fertility by a direct effect on

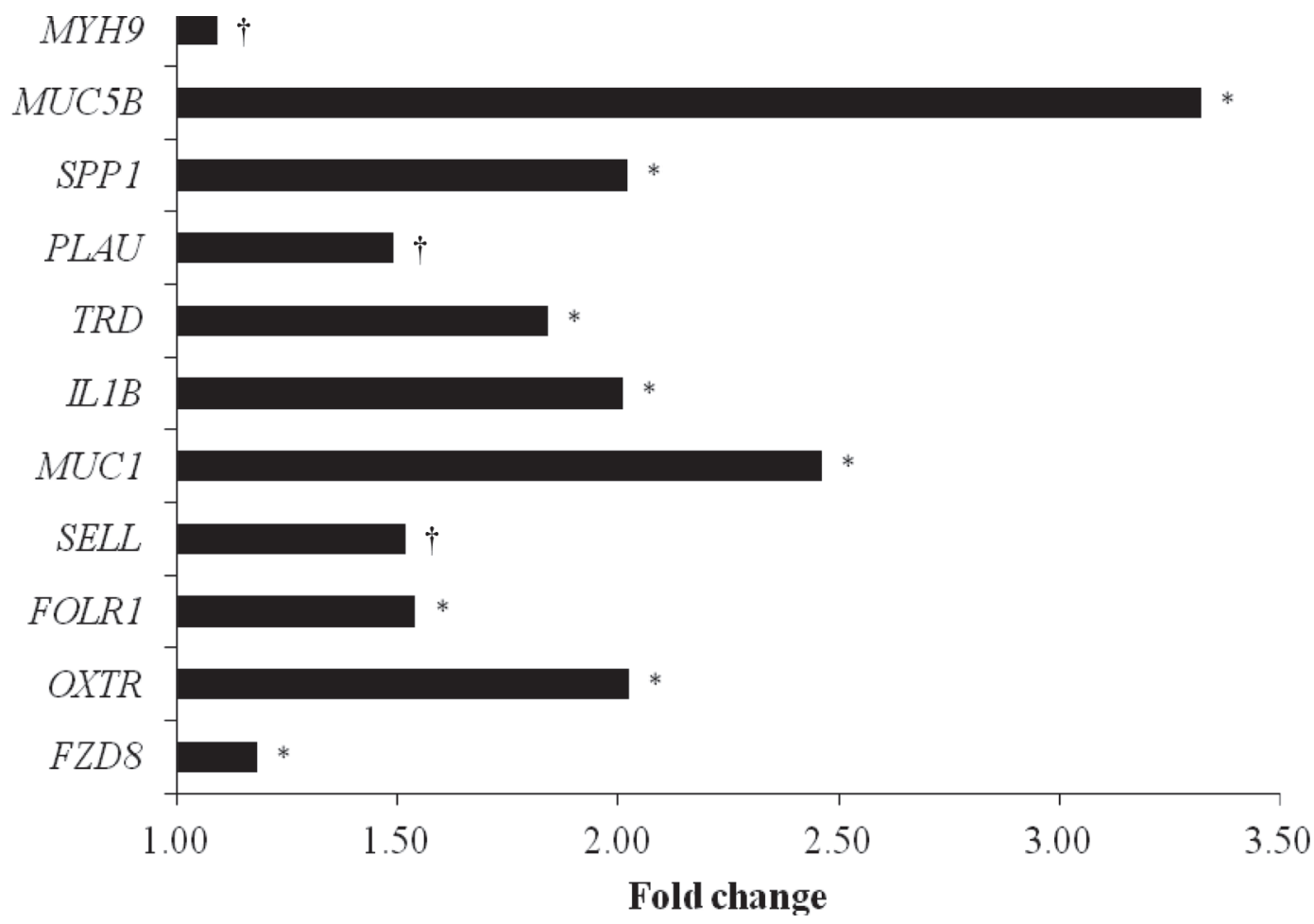

Figure 1. Relative fold change of differential mRNA expression in the endometrium from control (Con; $\mathrm{n}=7)$ and rumen-protected $\mathrm{B}$ vitamins $(\mathrm{VB} ; \mathrm{n}=6)$ treatment cows on $\mathrm{d} 14$ of pregnancy. Control was used as the referent $(* P \leq 0.05, \dagger P=0.10)$. 


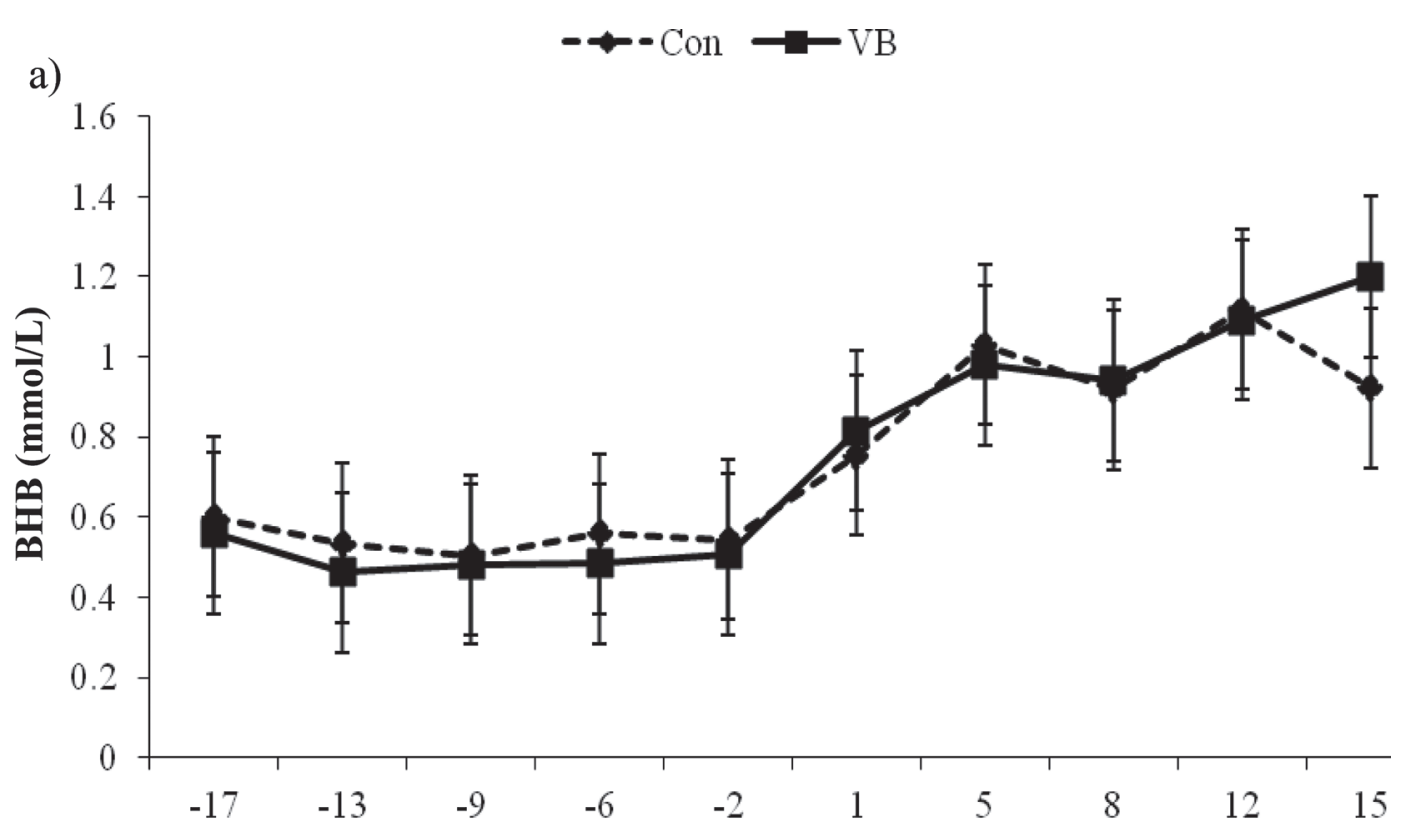

b)

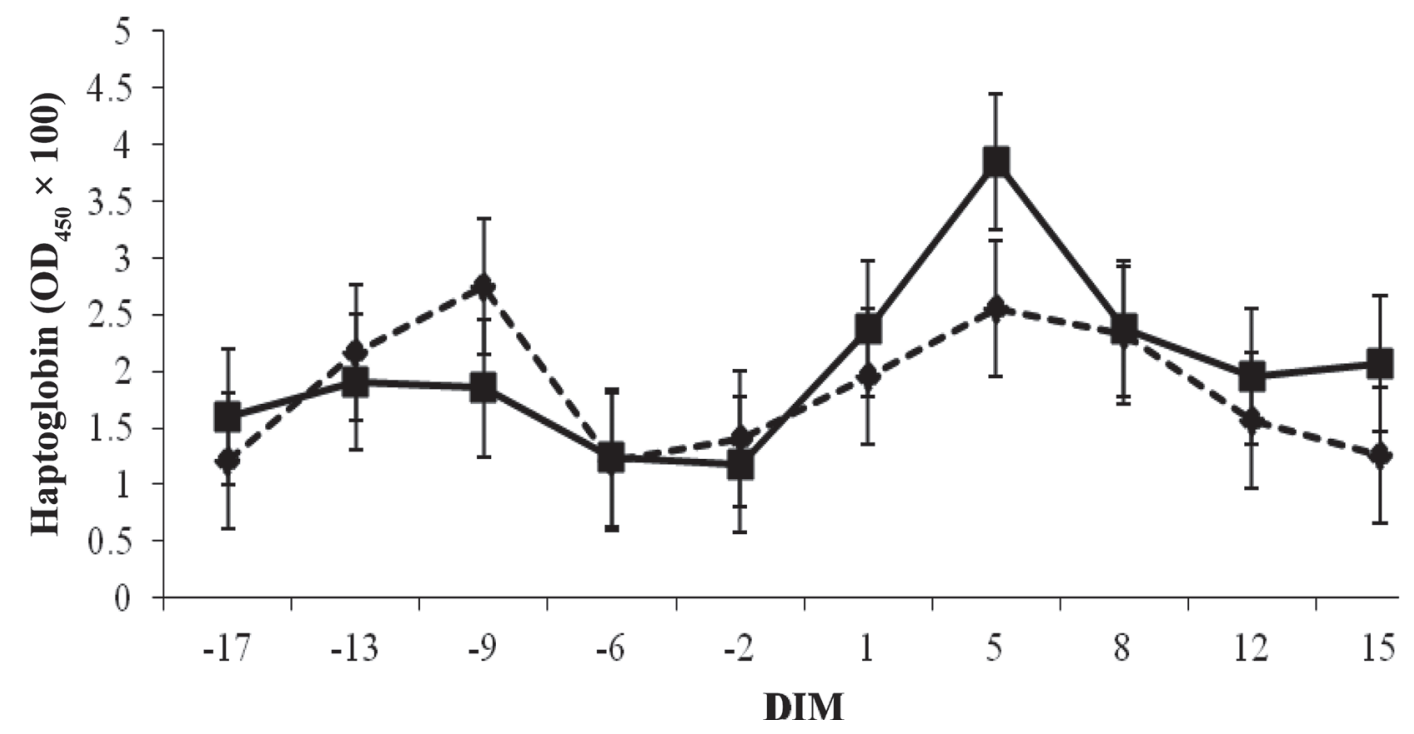

Figure 2. (a) Mean \pm SEM concentrations of BHB from control (Con; $\mathrm{n}=22$ ) and rumen-protected B vitamins $(\mathrm{VB} ; \mathrm{n}=20)$ groups during transition period $(P=0.84)$. (b) Mean \pm SEM concentrations of haptoglobin from Con $(\mathrm{n}=22)$ and VB $(\mathrm{n}=20)$ groups during the transition period. $\mathrm{OD}_{450}=$ optical density at $450 \mathrm{~nm}$.

synthesis of key molecules related to the early embryonic development in the endometrium.

\section{Milk Production, Blood Parameters, and Conceptus}

Supplementation with vitamin B molecules, either individually or in a complex, has delivered variable results on improving milk production and health in previous studies (Graulet et al., 2007; Sacadura et al.,
2008; Juchem et al., 2012). All B vitamins, as enzymatic co-factor or metabolic constituent, are crucial for proper functioning of metabolic processes such as Krebs cycle, gluconeogenesis, as well as metabolism of carbohydrates, fatty acids, and proteins (Depeint et al., 2006). The B vitamins during the transition period can potentially become a limiting nutrient in modern cows, therefore justifying additional supplementation during key periods of the lactation cycle. This role of B vita- 

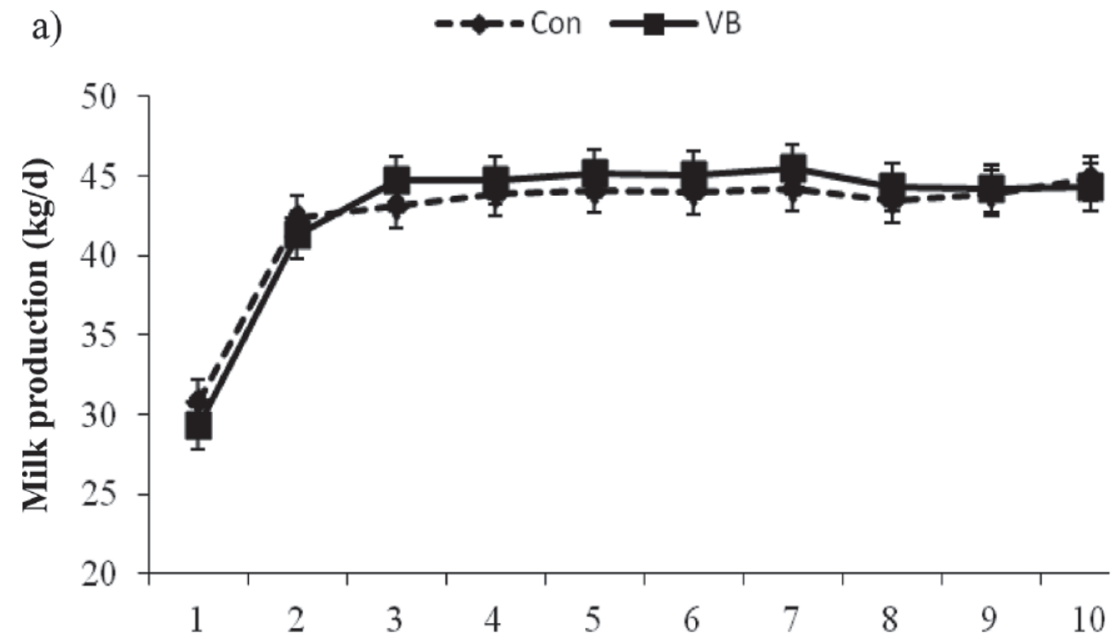

b) $\longrightarrow$ Con Fat $\rightarrow$ VBFat $\longrightarrow$ Con Protein $\longrightarrow$ VBProtein
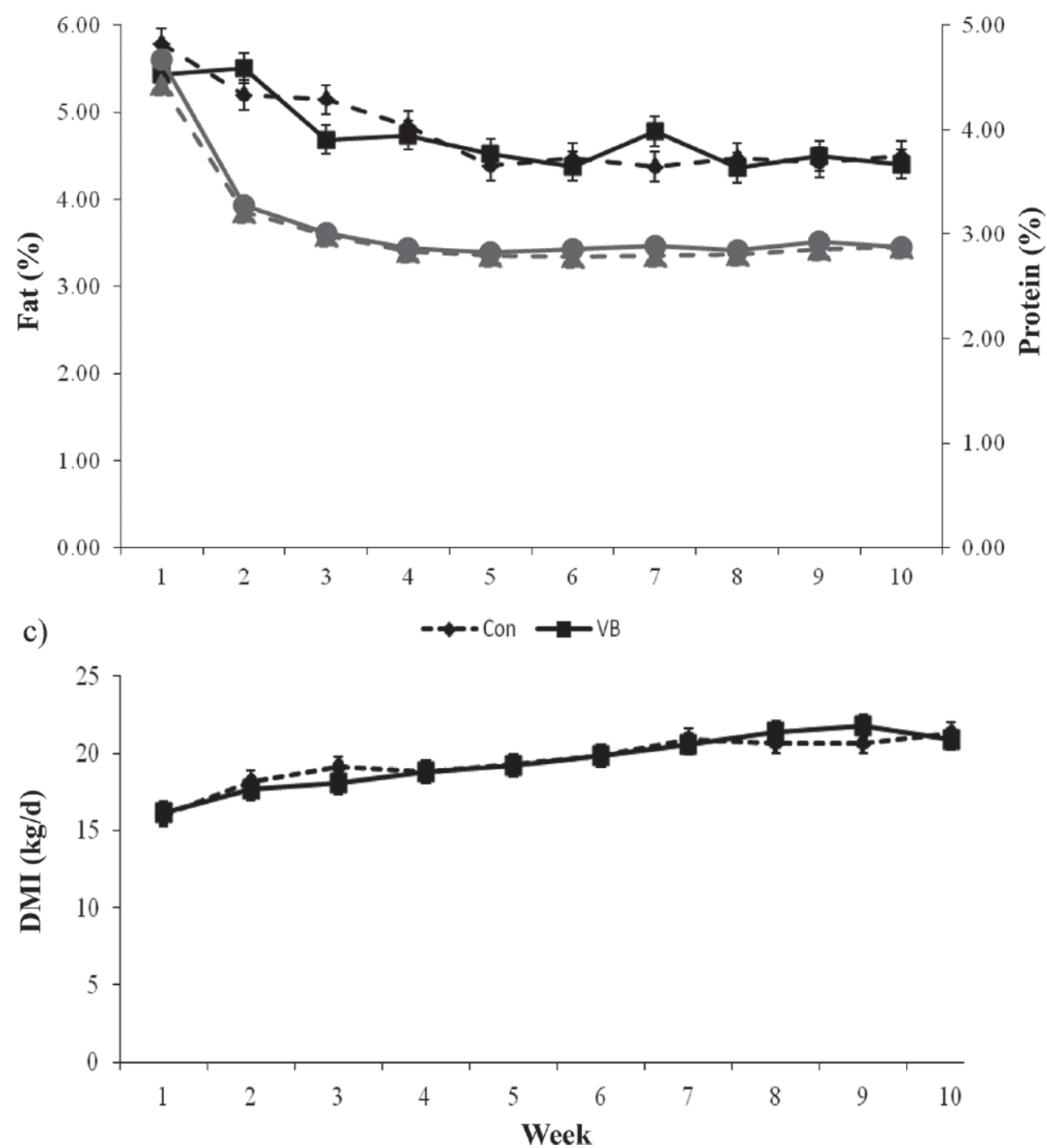

Figure 3. (a) Mean \pm SEM milk production $(\mathrm{kg} / \mathrm{d})$ from control (Con; $\mathrm{n}=22)$ and rumen-protected $\mathrm{B}$ vitamins $(\mathrm{VB} ; \mathrm{n}=20)$ groups for first 10 wk of lactation $(P=0.90)$. (b) Mean \pm SEM percentage fat $(P=0.86)$ and protein $(P=0.37)$ from Con $(\mathrm{n}=22)$ and VB $(\mathrm{n}=20)$ groups for first 10 wk of lactation. (c) Mean \pm SEM DMI $(\mathrm{kg} / \mathrm{d})$ from Con $(\mathrm{n}=22)$ and VB $(\mathrm{n}=20)$ groups for first 10 wk of lactation $(P=0.94)$. 


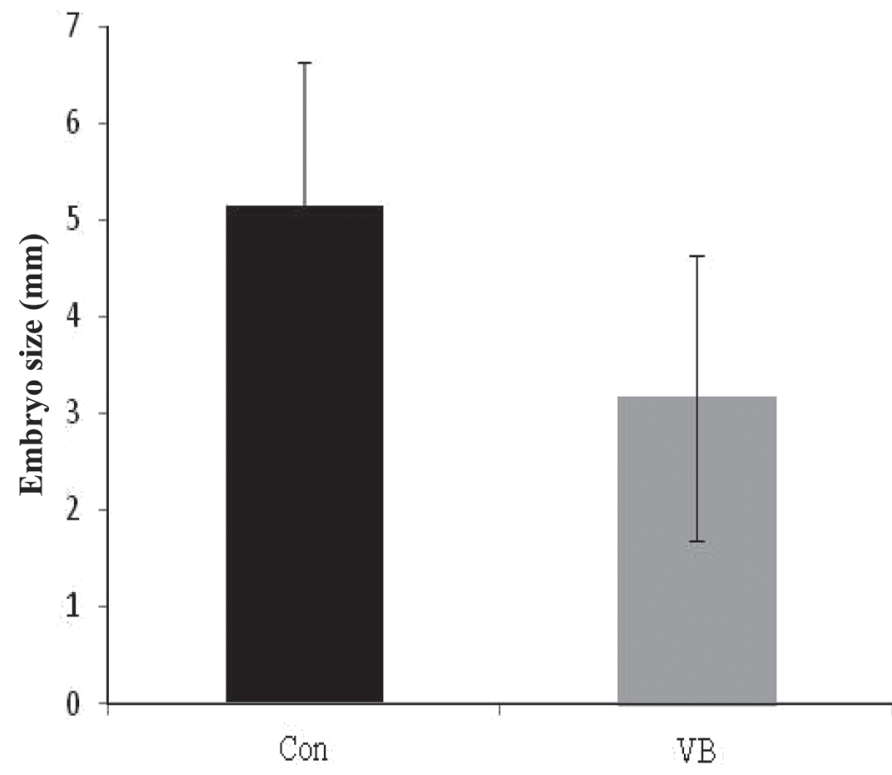

Figure 4. Mean \pm SEM length of conceptus collected from control $(\mathrm{Con} ; \mathrm{n}=7)$ and rumen-protected $\mathrm{B}$ vitamins $(\mathrm{VB} ; \mathrm{n}=6)$ cows on $\mathrm{d}$ 14 of pregnancy $(P=0.49)$.

mins in metabolic pathways could lead to an indirect downstream effect on the endometrial mRNA expression changes as well.

However, in this study, differences in milk production or components as well as metabolic parameters between the 2 groups over a period of 10 wk postcalving were not observed. It is unclear whether the VB treatment could cause an improvement in milk solids or ECM as a whole as initially hypothesized. Since there was not inclusion of animals suffering from clinical postpartum disorders, this might have removed possible differences between treatments. In addition, the relatively small number of animals in each treatment and only inclusion of multiparous animals might have erased a possible difference. The results are in contrast with others, but the current experiment is not a field trial with a large number of cows and the experimental design might have been a limitation. Similarly, the lack of differences in the concentrations of whole-blood BHB and haptoglobin in serum postpartum indicate a similar metabolic and inflammatory status for both groups in the transition period. Again, this might have been associated with the experimental design and inclusion of only clinically healthy cows in the analysis. The differences observed in previous studies could have been directly linked to a smaller frequency of clinical and sub-clinical postpartum disease and probably warrant further studies and analysis.

We also noticed a very low embryo recovery rate in this study (31\%). This was primarily due to unexpectedly high temperatures in the region from mid-July to mid-September. Including only the animals flushed during cooler months, the collection rate (46\%) was comparable to some of our previous studies. In spite of some important changes in the endometrial mRNA expression, the recovery rate and length of the conceptus were also similar between the 2 treatments. The recovery rate was not a variable expected to be modified because of the relatively low number of collections. The length of the conceptus, however, was indeed expected to be different. But the lack of difference does not necessarily mean lack of endometrium change, as was indeed observed in the present study. The variation of

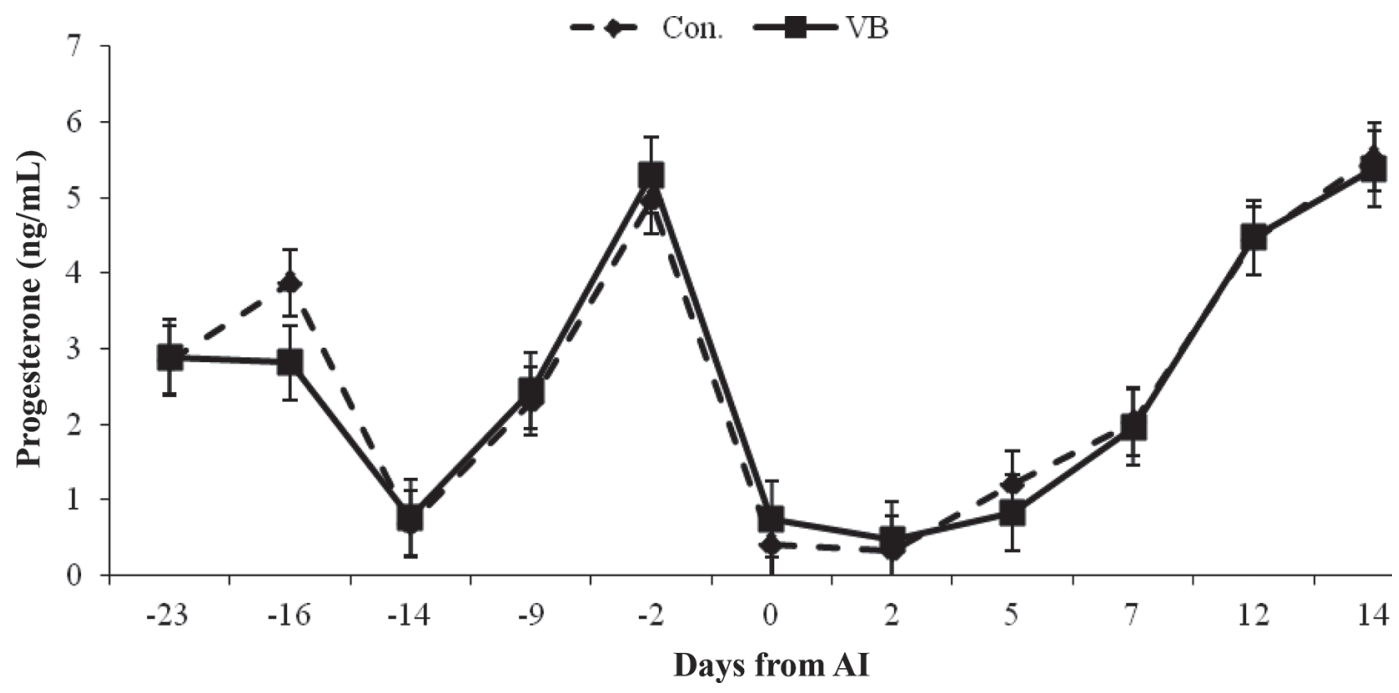

Figure 5. Mean \pm SEM progesterone concentrations from control (Con; $\mathrm{n}=22)$ and rumen-protected $\mathrm{B}$ vitamins $(\mathrm{VB} ; \mathrm{n}=20)$ groups at different time points during and after the synchronization protocol and after AI $(P=0.8)$. Day $0=\mathrm{AI}$. 
conceptus length in the pre-attachment phase is quite large (Ribeiro et al., 2016) and only a few factors such as progesterone (Forde et al., 2010) and the expression of estrus (Davoodi et al., 2016) have been shown to promote significant changes in conceptus length. In this case, the differences from supplemental B vitamins during the transition and early lactation are probably more subtle. One factor that was not addressed in the present study was the influence of the sex of the conceptus on the endometrium mRNA expression.

\section{Endometrial mRNA Expression}

The discussion below focuses on major individual transcripts and functional groups upregulated by dietary supplemental B vitamins with potential to improve the conceptus-endometrium communication in early pregnancy in dairy cattle. Before starting more specific discussion on the endometrium transcriptome, it is noteworthy to recognize that the in vivo endometrium biopsy can indeed carry a possible bias regarding the ratio of caruncular to inter-caruncular tissue collected. In spite of this possibility, several studies have been conducted using such technique and able to detect expected differences when dealing with known factors to affect the uterine mRNA expression, such as time of early pregnancy and pregnancy status, as well as ovarian steroid profile.

Immune System and Adhesion Molecules. The local uterine immune system is intensively regulated during the preimplantation and implantation phases of pregnancy (Bauersachs et al., 2006; Beltman et al., 2010). Inflammation around the site of cell division and differentiation, as it happens during embryogenesis and placentation, is partly regulated by the paracrine action of cytokines (Ben-Rafael and Orvieto, 1992). In VB cows, we saw an upregulation of $I L 1 B$, which is believed to play a role in tissue remodeling, embryo attachment, and placentation process (Rossi et al., 2005). Addition of IL-1 $\beta$ to bovine embryos in vitro had a positive effect on growth of the blastocysts (Paula-Lopes et al., 1998). Similarly, Ideta et al. (2010) reported a significantly higher pregnancy rate in heifers that had peripheral blood mononuclear cells, with high IL1B expression, administered in the uterine horns. In pigs, an increased $I L 1 B$ expression around the time of maternal recognition of pregnancy causing an increase in prostaglandin $\mathrm{E}_{2}$ secretion, which blocks luteolysis (Franczak et al., 2010). The potential benefits of upregulation of this gene in VB cows could be due to its role in preparing the uterus for implantation via pro-inflammatory mechanisms as well as providing immuno-tolerance via downstream effects on cytokines and growth factors in the uterus (Rossi et al., 2005; Geisert et al., 2012).
Another upregulated gene of interest was $T R D$, which encodes a T-cell receptor delta locus and plays a role in modulating the local maternal immune function. Women with recurrent pregnancy losses had a significantly decreased concentration of these cells in their uterus, compared with women carrying normal gestations (Ditzian-Kadanoff et al., 1993). Greater number of $\gamma \delta \mathrm{T}$ cells is the uterus of pregnant mice has also been reported, compared with nonpregnant ones (Heyborne et al., 1992). The upregulation of TRD animals can be beneficial to embryo survival because of the important role of $\gamma \delta \mathrm{T}$ cells in enabling early embryonic implantation and survival by inducing local intrauterine tolerance to embryo through suppression of anti-fetal immune response in the uterus (Suzuki et al., 1995; Fan et al., 2011).

We also observed an upregulation of $M U C 1$ in VB animals. MUC1 produces the protein mucin 1, an antiadhesion molecule, which acts as the first line of immune defense by lining the respiratory and reproductive tracts. MUC1 is downregulated at the site of embryo implantation in rodents, sheep, and pigs (Johnson et al., 2001; Aplin and Kimber, 2004). Hashizume (2007) observed an increased expression of mucins in bovine endometrium around d 14 of pregnancy, which is similar to our observation, and right before implantation on d 21, the MUC1 expression was downregulated in pregnant uterus. Aplin et al. (1998) suggested that surface modification of epitopes on $M U C 1$, by decreased sulfation can promote adhesion by reducing repulsion between the embryo and uterine epithelium. The MUC1 protein also interacts with L-selectin, further supporting this proposal (Lagow et al., 1999). However, more evidence is needed to establish the role and regulation of $M U C 1$ in bovine during peri-implantation period in cattle.

L-selectin is a cell surface adhesion molecule that is produced by neutrophils' expression of SELL. Østrup et al. (2010) reported a significantly increased expression of $S E L L$ in the endometrium of pregnant sows on d 14 of pregnancy. Similar to its function in lymphocytes, L-selectin acts as a receptor to facilitate adhesion of the embryo to the surface epithelium of the uterine endometrium (Genbacev et al., 2003). The increased expression and interactions of these molecules with the embryo in the peri-implantation and implantation phase would aid in the apposition as well as implantation process.

The SPP1 gene regulates production of secreted phosphoprotein 1. Dunlap et al. (2008) suggested the role of SPP1 in tissue remodeling at the uterine attachment site by affecting cell-cell communication and cellextracellular matrix communication, and increasing cell proliferation. An increased expression of SPP1 has been 
reported in the endometrium of both pigs and sheep during early pregnancy (Bazer, 2013; Samborski et al., 2013; Kim et al., 2015). Kim et al. (2015) suggested that, similar to humans, upregulation of SPP1 could be critical for cell-cell and cell-extracellular matrix adhesion in noninvasive placentation that is seen in pigs, as well as in ruminants such as cows.

The $M U C 5 B$ gene encodes mucin $5 \mathrm{~B}$, which is one of the major gel-forming mucins in mucus. It is particularly important in aiding the transport of sperm to the uterus and later on in formation of the cervical plug during pregnancy. However, not much has been reported on the role of $M U C 5 B$ in the endometrium. Altmäe et al. (2010) reported an upregulation of $M U C 5 B$ in women with unexplained infertility at the time of embryo implantation. However, we observed upregulation of $M U C 5 B$ in the preimplantation phase of pregnancy, in VB cows. Further research on MUC5B expression in the endometrium, before and during the implantation, is required to determine its role in the pregnant uterus.

Oxytocin Regulation. The OXTR gene, which regulates oxytocin receptor expression, has been reported to be downregulated in pregnant animals (Spencer et al., 2004; Bazer et al., 2012). The expression of this gene is regulated by action of progesterone as well as IFN- $\tau$. Even though $O X T R$ and $O X T$ genes are reportedly downregulated in pregnant animals, we observed greater expression of $O X T R$ in VB pregnant animals. Similar results were reported by Jenner et al. (1991), who observed an increased $O X T R$ on d 12 after estrus in pregnant as well as nonpregnant cows. It is still unclear based on the current results whether an increase in mRNA expression for $O X T R$ would result in greater local synthesis of prostaglandin F $2 \alpha$ that could, at the appropriate time, aid the placentation process.

Nutrient Transporter. We analyzed several nutrient transporters in the endometrium and observed that FOLR1 was a transcript upregulated in VB cows. This gene codes for folate receptor 1 , which helps in transporting folic acid and its derivatives, primarily 5 -methyltetrahydrofolate, to the inside of the cells. 5 -Methyltetrahydrofolate is the biologically active form of vitamin $\mathrm{B}_{9}$ (folate) and is an important player in DNA synthesis (Pauwels et al., 2016), and along with choline and methionine, in epigenetic changes such as methylation of DNA and RNA (Fenech, 2012) and onecarbon metabolism (Depeint et al., 2006). Although folate deficiency does not affect implantation, it plays an important role in fetal growth and development and its deficiency has been reported to cause fetal defects and even preterm death in humans (Guèant et al., 2013). Upregulation of FOLR1 indicates an active folate cycle in the endometrium in the preimplantation period. The FOLR 1 could potentially play a part in cell modification at the implantation site and later support of the growing embryo caused by DNA synthesis and regulation.

\section{CONCLUSIONS}

Strategic supplementation with rumen-protected B vitamins improved the markup of some key genes necessary for pregnancy establishment. The exact mechanisms behind these changes are still not clear; however, we believe the upregulation of important genes in the preimplantation endometrium could be a direct action of vitamin B molecules in the endometrium. The current study was not designed to differentiate between direct and indirect effects of rumen-protected B-vitamin complex supplementation in the endometrium mRNA expression. Considering the nonsignificant differences in BHB, haptoglobin, and progesterone between the treatments, we are inclined to propose that the changes here observed were direct in nature, which would pertain to the involvement of $\mathrm{B}$ vitamins in genomic modifications.

\section{ACKNOWLEDGMENTS}

We thank the Natural Science and Engineering Research Council (NSERC; Ottawa, ON, Canada), the Mitacs Accelerate Program (Vancouver, BC, Canada), and Jefo (St. Hyacynthe, QC, Canada) for the financial contribution. We also thank all the students and technicians who assisted in the collection and processing of data at the University of British Columbia Dairy Education and Research Center (Agassiz, BC, Canada).

\section{REFERENCES}

Altmäe, S., J. A. Martínez-Conejero, A. Salumets, C. Simón, J. A Horcajadas, and A. Stavreus-Evers. 2010. Endometrial gene expression analysis at the time of embryo implantation in women with unexplained infertility. Mol. Hum. Reprod. 16:178-187. https: //doi.org/10.1093/molehr/gap102.

Aplin, J. D., N. A. Hey, and R. A. Graham. 1998. Human endometrial MUC1 carries keratan sulfate: Characteristic glycoforms in the luminal epithelium at receptivity. Glycobiology 8:269-276. https:/ /doi.org/10.1093/glycob/8.3.269.

Aplin, J. D., and S. J. Kimber. 2004. Trophoblast-uterine interactions at implantation. Reprod. Biol. Endocrinol. 2:48. https://doi.org/ 10.1186/1477-7827-2-48.

Bauersachs, S., S. E. Ulbrich, K. Gross, S. E. M. Schmidt, H. H. D Meyer, H. Wenigerkind, M. Vermehren, F. Sinowatz, H. Blum, and E. Wolf. 2006. Embryo-induced transcriptome changes in bovine endometrium reveal species-specific and common molecular markers of uterine receptivity. Reproduction 132:319-331. https://doi .org/10.1530/rep.1.00996.

Bazer, F. W. 2013. Pregnancy recognition signaling mechanisms in ruminants and pigs. J. Anim. Sci. Biotechnol. 4:23. https://doi .org/10.1186/2049-1891-4-23.

Bazer, F. W., G. Song, and W. W. Thatcher. 2012. Roles of conceptus secretory proteins in establishment and maintenance of pregnancy 
in ruminants. Asian-australas. J. Anim. Sci. 25:1-16. https://doi .org/10.5713/ajas.2011.r.08.

Beltman, M. E., N. Forde, P. Furney, F. Carter, J. F. Roche, P. Lonergan, and M. A. Crowe. 2010. Characterisation of endometrial gene expression and metabolic parameters in beef heifers yielding viable or non-viable embryos on day 7 after insemination. Reprod. Fertil. Dev. 22:987-999. https://doi.org/10.1071/RD09302.

Ben-Rafael, Z., and R. Orvieto. 1992. Cytokines-Involvement in reproduction. Fertil. Steril. 58:1093-1099. https://doi.org/10.1016/ S0015-0282(16)55548-4.

Canadian Council on Animal Care (CCAC). 2009. The Care and Use of Farm Animals in Research, Teaching and Testing. Canadian Council for Animal Care, Ottawa, Ontario, Canada.

Cerri, R. L. A., I. M. Thompson, I. H. Kim, A. D. Ealy, P. J. Hansen, C. R. Staples, J. L. Li, and W. W. Thatcher. 2012. Effects of lactation and pregnancy on endometrial gene expression in dairy cattle. J. Dairy Sci. 95:5657-5675. https://doi.org/10.3168/jds 2011-5114.

Chen, B., C. Wang, Y. M. Wang, and J. X. Liu. 2011. Effect of biotin on milk performance of dairy cattle: A meta-analysis. J. Dairy Sci. 94:3537-3546. https://doi.org/10.3168/jds.2010-3764.

Davoodi, S., R. F. Cooke, A. C. Fernandes, B. I. Cappellozza, J. L. M. Vasconcelos, and R. L. Cerri. 2016. Expression of estrus modifies the gene expression profile in reproductive tissues on Day 19 of gestation in beef cows. Theriogenology 85:645-655.

Depeint, F., W. R. Bruce, N. Shangari, R. Mehta, and P. J. O'Brien. 2006. Mitochondrial function and toxicity: Role of B vitamins on the one-carbon transfer pathways. Chem. Biol. Interact. 163:113132. https://doi.org/10.1016/j.cbi.2006.05.010.

Ditzian-Kadanoff, R., J. Garon, M. S. Verp, and M. Zilberstein. 1993. Gamma delta T cells in human decidua. Am. J. Obstet. Gynecol. 168:831-836.

Dunlap, K. A., D. W. Erikson, R. C. Burghardt, F. J. White, K. M. Reed, J. L. Farmer, T. E. Spencer, R. R. Magness, F. W. Bazer, K. J. Bayless, and G. A. Johnson. 2008. Progesterone and placentation increase secreted phosphoprotein one (SPP1 or osteopontin) in uterine glands and stroma for histotrophic and hematotrophic support of ovine pregnancy. Biol. Reprod. 79:983-990. https://doi .org/10.1095/biolreprod.108.071068.

Duplessis, M., C. L. Girard, D. E. Santschi, J.-P. Laforest, J. Durocher, and D. Pellerin. 2014. Effects of folic acid and vitamin $\mathrm{B}_{12}$ supplementation on culling rate, diseases, and reproduction in commercial dairy herds. J. Dairy Sci. 97:2346-2354. https://doi .org/10.3168/jds.2013-7369.

Evans, E., and D. T. Mair. 2013. Effects of a rumen protected B vitamin blend substituted for biotin upon milk production and component yield in lactating dairy cows. Open J. Anim. Sci. 3:93-98. https://doi.org/10.4236/ojas.2013.32014.

Fan, D. X., J. Duan, M. Q. Li, B. Xu, D. J. Li, and L. P. Jin. 2011. The decidual gamma-delta $T$ cells up-regulate the biological functions of trophoblasts via IL-10 secretion in early human pregnancy. Clin. Immunol. 141:284-292. https://doi.org/10.1016/j.clim.2011 .07 .008 .

Fenech, M. 2012. Folate (vitamin $\mathrm{B}_{9}$ ) and vitamin $\mathrm{B}_{12}$ and their function in the maintenance of nuclear and mitochondrial genome integrity. Mutat. Res. 733:21-33. https://doi.org/10.1016/ j.mrfmmm.2011.11.003.

Forde, N., M. E. Beltman, G. Duffy, A. Lee, J. F. Roche, P. Lonergan, and M. Crowe. 2010. A delay in the down-regulation of the nuclear progesterone receptor from the luminal epithelium in heifers with low progesterone (P4), alters the temporal expression pattern of genes that are known to enhance conceptus development. Biol. Reprod. 83:347. https://doi.org/10.1093/biolreprod/83.s1.347.

Franczak, A., A. Zmijewska, B. Kurowicka, B. Wojciechowicz, and G. Kotwica. 2010. Interleukin 1 $\beta$-induced synthesis and secretion of prostaglandin E2 in the porcine uterus during various periods of pregnancy and the estrous cycle. J. Physiol. Pharmacol. 61:733742 .

Gagnon, A., D. R. Khan, M.-A. Sirard, C. L. Girard, J.-P. Laforest, and F. J. Richard. 2015. Effects of intramuscular administration of folic acid and vitamin $B_{12}$ on granulosa cells gene expression in postpartum dairy cows. J. Dairy Sci. 98:7797-7809. https://doi .org/10.3168/jds.2015-9623.

Geisert, R., A. Fazleabas, M. Lucy, and D. Mathew. 2012. Interaction of the conceptus and endometrium to establish pregnancy in mammals: Role of interleukin 1 $\beta$. Cell Tissue Res. 349:825-838. https:/ /doi.org/10.1007/s00441-012-1356-1.

Genbacev, O. D., A. Prakophol, R. Foulk, A. Krtolica, D. Illic, M. S. Singer, Z. Yang, L. Kiessling, S. D. Rosen, and S. J. Fisher. 2003. Trophoblast L-selectin-mediated adhesion at the maternal-fetal interface. Science 299:405-408.

Graulet, B., J. J. Matte, A. Desrochers, L. Doepel, M.-F. Palin, and C. L. Girard. 2007. Effects of dietary supplements of folic acid and vitamin $\mathrm{B}_{12}$ on metabolism of dairy cows in early lactation. J. Dairy Sci. 90:3442-3455. https://doi.org/10.3168/jds.2006-718.

Guèant, J. L., F. Namour, R. M. Gue'ant-Rodriguez, and J. L. Daval. 2013. Folate and fetal programming: A play in epigenomics? Trends Endocrinol. Metab. 24:279-289. https://doi.org/10.1016/j tem.2013.01.010.

Hashizume, K. 2007. Analysis of uteroplacental-specific molecules and their functions during implantation and placentation in the bovine. J. Reprod. Dev. 53:1-11.

Heyborne, K. D., R. L. Cranfill, S. R. Carding, W. K. Born, and R. L. O'Brien. 1992. Characterization of gamma delta T lymphocytes at the maternal-fetal interface. J. Immunol. 149:2872-2878.

Ideta, A., S. Ichi Sakai, Y. Nakamura, M. Urakawa, K. Hayama, K. Tsuchiya, H. Fujiwara, and Y. Aoyagi. 2010. Administration of peripheral blood mononuclear cells into the uterine horn to improve pregnancy rate following bovine embryo transfer. Anim. Reprod. Sci. 117:18-23. https://doi.org/10.1016/j.anireprosci.2009.04.004.

Iwersen, M., U. Falkenberg, R. Voigtsberger, D. Forderung, and W. Heuwieser. 2009. Evaluation of an electronic cowside test to detect subclinical ketosis in dairy cows. J. Dairy Sci. 92:2618-2624. https: //doi.org/10.3168/jds.2008-1795.

Jenner, L. J., T. J. Parkinson, and G. E. Lamming. 1991. Uterine oxytocin receptors in cyclic and pregnant cows. J. Reprod. Fertil. 91:49-58.

Johnson, G. A., F. W. Bazer, L. A. Jaeger, H. Ka, J. E. Garlow, C. Pfarrer, T. E. Spencer, and R. C. Burghardt. 2001. Muc-1, integrin, and osteopontin expression during the implantation cascade in sheep. Biol. Reprod. 65:820-828. https://doi.org/10.1095/ biolreprod65.3.820.

Juchem, S. O., P. H. Robinson, and E. Evans. 2012. A fat based rumen protection technology post-ruminally delivers a B vitamin complex to impact performance of multiparous Holstein cows. Anim. Feed Sci. Technol. 174:68-78. https://doi.org/10.1016/j.anifeedsci.2012 .03.004.

Kim, M., H. Seo, Y. Choi, I. Yoo, M. Seo, C. K. Lee, H. Kim, and H. Ka. 2015. Analysis of stage-specific gene expression profiles in the uterine endometrium during pregnancy in pigs. PLoS One 10:e0143436. https://doi.org/10.1371/journal.pone.0143436.

Lagow, E., M. M. DeSouza, and D. D. Carson. 1999. Mammalian reproductive tract mucins. Hum. Reprod. Update 5:280-292. https:/ /doi.org/10.1093/humupd/5.4.280.

Li, H. Q., Q. Liu, C. Wang, Z. M. Yang, G. Guo, W. J. Huo, C. X. Pei, Y. L. Zhang, S. L. Zhang, H. Wang, J. X. Liu, and Y. X. Huang. 2016. Effects of dietary supplements of rumen-protected folic acid on lactation performance, energy balance, blood parameters and reproductive performance in dairy cows. Anim. Feed Sci. Technol. 213:55-63. https://doi.org/10.1016/j.anifeedsci.2016.01.005.

Makimura, S., and N. Suzuki. 1982. Quantitative determination of bovine serum haptoglobin and its elevation in some inflammatory diseases. Nippon Juigaku Zasshi 44:15-21.

NRC. 2001. Nutrient Requirements of Dairy Cattle. 7th rev. ed. Natl. Acad. Sci., Washington, DC.

Østrup, E., S. Bauersachs, H. Blum, E. Wolf, and P. Hyttel. 2010 Differential endometrial gene expression in pregnant and nonpregnant sows. Biol. Reprod. 83:277-285. https://doi.org/10.1095/ biolreprod.109.082321.

Paula-Lopes, F. F., A. A. S. de Moraes, J. L. Edwards, J. E. Justice, and P. J. Hansen. 1998. Regulation of preimplantation develop- 
ment of bovine embryos by interleukin-1 $\beta 1$. Biol. Reprod. 59:14061412. https://doi.org/10.1095/biolreprod59.6.1406.

Pauwels, S., R. C. Duca, R. Devlieger, K. Freson, D. Straetmans, E. Van Herck, I. Huybrechts, G. Koppen, and L. Godderis. 2016. Maternal methyl-group donor intake and global DNA (Hydroxy) methylation before and during pregnancy. Nutrients 8 . https://doi .org/10.3390/nu8080474.

Ribeiro, E. S., L. F. Greco, R. S. Bisinotto, F. S. Lima, W. W. Thatcher, and J. E. Santos. 2016. Biology of preimplantation conceptus at the onset of elongation in dairy cows. Biol. Reprod. 94:97. https:/ /doi.org/10.1095/biolreprod.115.134908.

Richard, F., D. R. Khan, C. L. Girard, H. Leclerc, and E. Evans. 2016. Effects of a dietary supplementation of rumen-protected B vitamins on reproduction of dairy cows by measuring nutrigenomic parameters. J. Anim. Sci. 94(Suppl 5):552. https://doi.org/10.2527/ jam2016-1150.

Rossi, M., A. M. Sharkey, P. Viganò, G. Fiore, R. Furlong, P. Florio, G. Ambrosini, S. K. Smith, and F. Petraglia. 2005. Identification of genes regulated by interleukin-1beta in human endometrial stromal cells. Reproduction 130:721-729. https://doi.org/10.1530/ rep.1.00688.

Sacadura, F. C., P. H. Robinson, E. Evans, and M. Lordelo. 2008. Effects of a ruminally protected B-vitamin supplement on milk yield and composition of lactating dairy cows. Anim. Feed Sci. Technol. 144:111-124. https://doi.org/10.1016/j.anifeedsci.2007.10.005.

Samborski, A., A. Graf, S. Krebs, B. Kessler, and S. Bauersachs. 2013. Deep sequencing of the porcine endometrial transcriptome on day
14 of pregnancy. Biol. Reprod. 88:84. https://doi.org/10.1095/ biolreprod.113.107870.

Santschi, D. E., R. Berthiaume, J. J. Matte, A. F. Mustafa, and C. L. Girard. 2005. Fate of supplementary B-vitamins in the gastrointestinal tract of dairy cows. J. Dairy Sci. 88:2043-2054. https://doi .org/10.3168/jds.S0022-0302(05)72881-2.

Schwab, E. C., C. G. Schwab, R. D. Shaver, C. L. Girard, D. E. Putnam, and N. L. Whitehouse. 2006. Dietary forage and nonfiber carbohydrate contents influence B-vitamin intake, duodenal flow, and apparent ruminal synthesis in lactating dairy cows. J. Dairy Sci. 89:174-187. https://doi.org/10.3168/jds.S0022-0302(06)72082 -3 .

Spencer, T. E., R. Burghardt, G. Johnson, and F. Bazer. 2004. Conceptus signals for establishment and maintenance of pregnancy. Anim. Reprod. Sci. 82-83:537-550. https://doi.org/10.1016/j .anireprosci.2004.04.014.

Spencer, T. E., O. Sandra, and E. Wolf. 2008. Genes involved in conceptus-endometrial interactions in ruminants: Insights from reductionism and thoughts on holistic approaches. Reproduction 135:165-179. https://doi.org/10.1530/REP-07-0327.

Suzuki, T., K. Hiromatsu, Y. Ando, T. Okamoto, Y. Tomoda, and Y. Yoshikai. 1995. Regulatory role of gamma delta T cells in uterine intraepithelial lymphocytes in maternal antifetal immune response. J. Immunol. 154:4476-4484.

\section{APPENDIX}

Table A1. List of genes and their target sequences

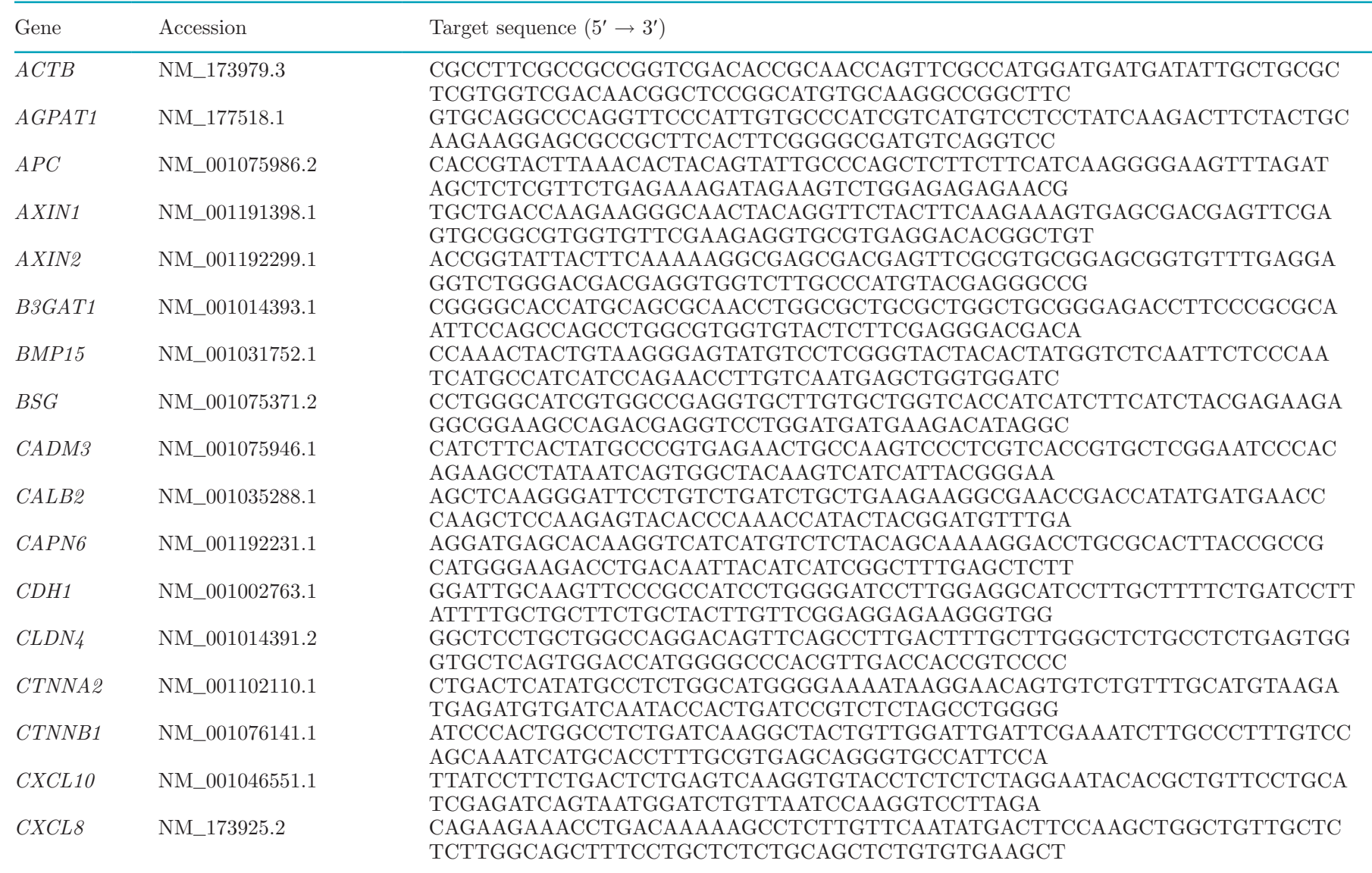


Table A1 (Continued). List of genes and their target sequences

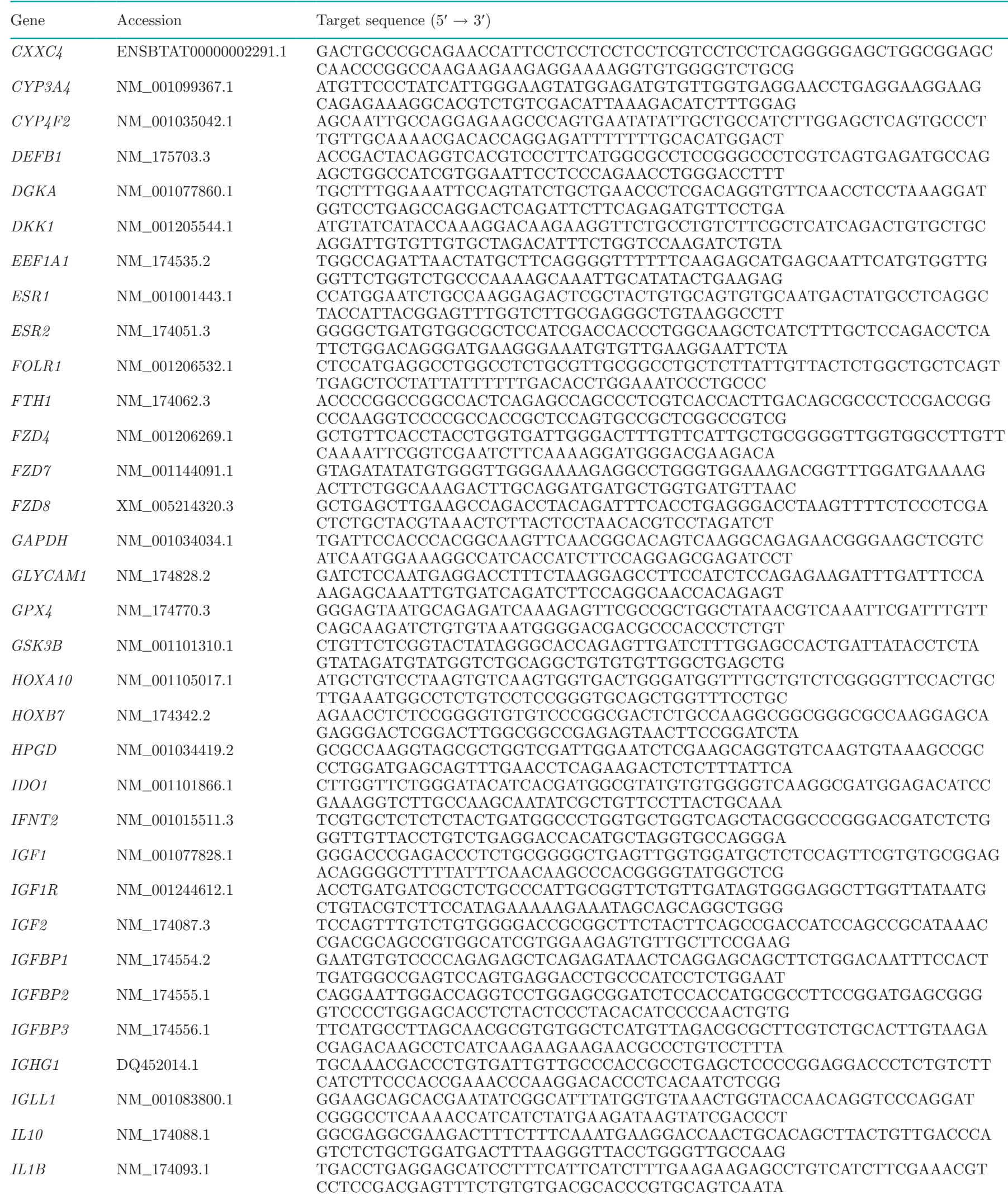


Table A1 (Continued). List of genes and their target sequences

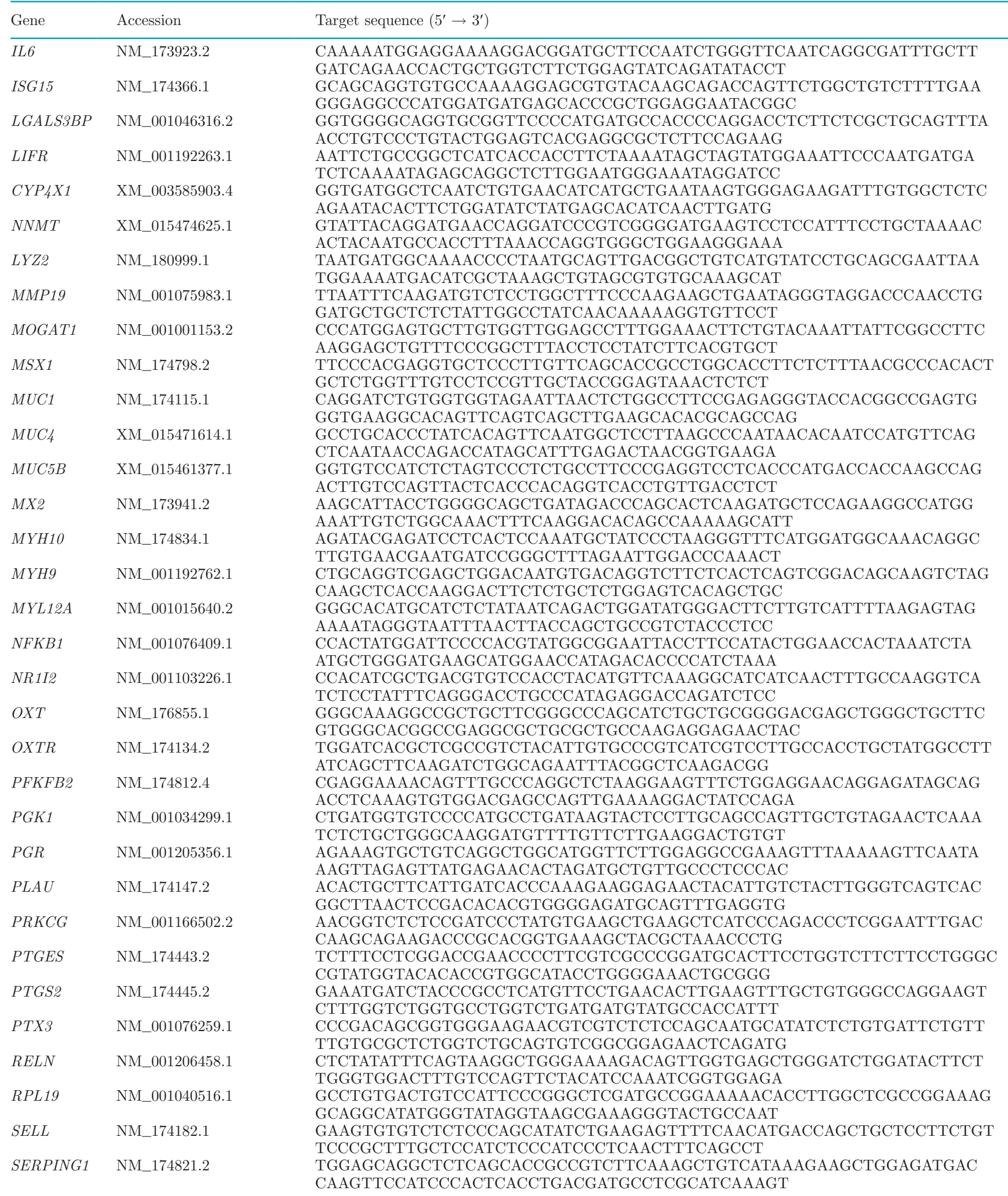


Table A1 (Continued). List of genes and their target sequences

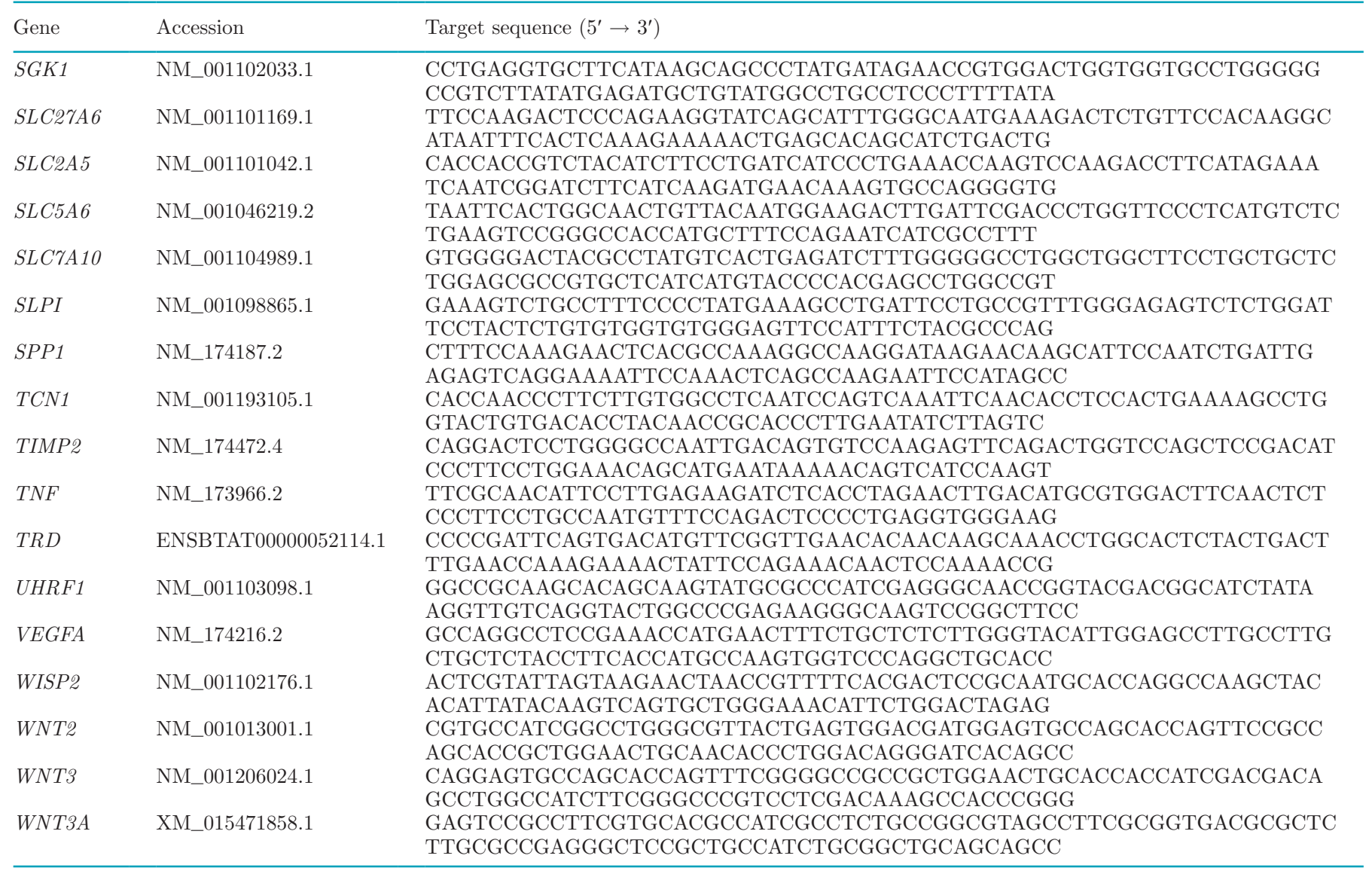

